\title{
RAZPRAVE
}

\section{MORFOMETRIČNI TIPI POKRAJINSKIH VROČIH IN MRZLIH TOČK V SLOVENIJI}

\author{
AVTORJA
}

\section{dr. Mauro Hrvatin}

Znanstvenoraziskovalni center Slovenske akademije znanosti in umetnosti, Geografski inštitut Antona Melika, Gosposka ulica 13, SI - 1000 Ljubljana, Slovenija mauro@zrc-sazu.si

\section{dr. Drago Perko}

Znanstvenoraziskovalni center Slovenske akademije znanosti in umetnosti, Geografski inštitut Antona Melika, Gosposka ulica 13, SI - 1000 Ljubljana, Slovenija

drago@zrc-sazu.si

DOI: $10.3986 / G V 90202$

UDK: 911.52:528:004(497.4)

COBISS: 1.01

\section{IZVLEČEK}

\section{Morfometrični tipi pokrajinskih vročih in mrzlih točk $v$ Sloveniji}

$\mathrm{Na}$ temelju digitalnih podatkov o reliefu, kamninah in rastlinstvu smo $z$ uporabo geografskega informacijskega sistema izračunali pokrajinsko raznolikost Slovenije. Območja z visoko pokrajinsko raznolikostjo so pokrajinske vroče točke, območja z nizko pokrajinsko raznolikostjo pa pokrajinske mrzle točke. Cilj raziskave je bil ugotoviti predvsem: ali za tako določene pokrajinske vroče in mrzle točke veljajo kakšne skupne značilnosti, ali jih je glede na te značilnosti mogoče razvrstiti v skupine in ali so posamezne skupine enotne, sestavljene samo iz vroči točk ali samo iz mrzlih točk, ali pa mešane, torej sestavljene hkrati iz vročih in mrzlih točk. Izbrali smo 20 po površini največjih pokrajinskih vročih točk in 20 po površini največjih pokrajinskih mrzlih točk in jih s pomočjo Wardove metode razvrstili v sedem tipov glede na dvajset morfometričnih kazalnikov. Od 40 pokrajinskih vročih in mrzlih točk sta se v nasprotno skupino uvrstili le dve, kar je komaj $5 \%$.

\section{KLJUČNE BESEDE}

geografija, pokrajinska raznolikost, pokrajinska vroča točka, pokrajinska mrzla točka, morfometrični kazalnik, geografski informacijski sistem, Wardova metoda

\section{Morphometric types of landscape hotspots and coldspots in Slovenia}

Based on digital data on relief, rock, and vegetation, a geographic information system was used to calculate landscape diversity of Slovenia. Areas with high landscape diversity are landscape hotspots, while areas with low landscape diversity are landscape coldspots. The aim of the study was to determine in particular, whether or not there are some common characteristics for such landscape hotspots and coldspots, whether they can be classified into groups according to these characteristics, and whether the individual groups are uniform, made up only of hotspots or coldspots, or mixed, that is, they are composed simultaneously from hotspots and coldspots. 
We selected the 20 largest landscape hotspots and the 20 largest landscape coldspots and classified them into seven morphometric types using the Ward's method in terms of twenty morphometric indicators. Of the 40 landscape hotspots and cold points, only two were ranked in the opposite group, which is barely $5 \%$.

\section{KEY WORDS}

geography, landscape diversity, landscape hotspot, landscape coldspot, morphometric indicator, geographic information system, Ward's method

Uredništvo je prispevek prejelo 23. maja 2018. 


\section{Uvod}

Pokrajinsko najbolj raznolika območja v Evropi ležijo v južni Skandinaviji ter vzdolž Pirenejev in Alp. Tu leži tudi Slovenija, ki je po eni od naših študij povprečno celo najbolj raznolika evropska država (Ciglič in Perko 2013). Toda tudi znotraj Slovenije so razlike med pokrajinami.

Pokrajinsko raznolikost Slovenije smo izračunali z geografskim informacijskim sistemom na temelju digitalnih podatkov o reliefu, kamninah in rastlinstvu. Območja z visoko pokrajinsko raznolikostjo smo imenovali pokrajinske vroče točke, območja z nizko pokrajinsko raznolikostjo pa pokrajinske mrzle točke (Perko, Ciglič in Hrvatin 2017). Kot vroče točke smo opredelili desetino Slovenije z najvišjo pokrajinsko raznolikostjo, kot mrzle točke pa desetino Slovenije z najnižjo pokrajinsko raznolikostjo.

Cilj raziskave je bil ugotoviti, ali za tako določene pokrajinske vroče in mrzle točke veljajo kakšne skupne značilnosti in ali jih je glede na te značilnosti mogoče razvrstiti v skupine. Ker je relief najpomembnejša sestavina notranje sestave in zunanje podobe večine slovenskih pokrajin, smo za razvrščanje izbrali morfološke kazalnike. Zanimalo nas je tudi, ali se bodo v posamezne skupine uvrstile samo vroče točke ali samo mrzle točke, ali pa bodo skupine mešane, torej sestavljene hkrati iz vročih in mrzlih točk.

V prispevku prikazujemo razvrščanje 20 prostorsko največjih pokrajinskih vročih točk in 20 prostorsko največjih pokrajinskih mrzlih točk glede na dvajset morfometričnih kazalnikov, zato končne skupine lahko opredelimo za morfološke skupine oziroma morfološke tipe pokrajinskih vročih in mrzlih točk.

Območja dvajsetih največjih vročih točk smo poimenovali po najbližjih naseljih (slika 4):

- Trbovlje-Laško,

- Tolmin (slika 1),

- Podsreda,

- Slovenske Konjice,

- Medvode-Domžale,

- Motnik,

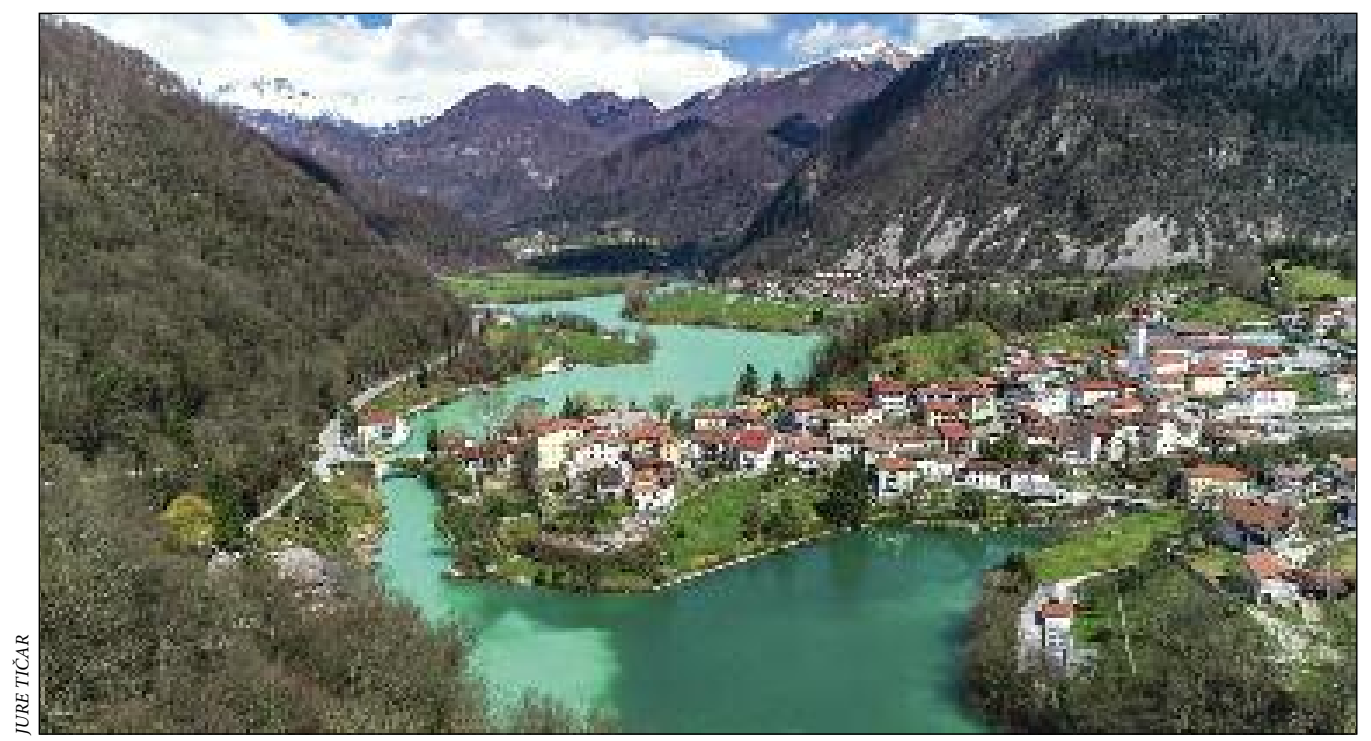

Slika 1: Razgibana pokrajina okrog Mosta na Soči je primer pokrajinske vroče točke Tolmin in spada $v$ skupino vročih točk $v$ alpskih hribovjih na stiku $z$ alpskimi ravninami, panonskimi gričevji in dinarskimi planotami ( $v$ konkretnem primeru vroče točke na stiku alpskega hribovja in dinarske planote). 
- Štore,

- Gornji Grad,

- Železniki,

- Sevnica,

- Velenje,

- Mežica,

- Komenda-Cerklje,

- Stranje-Črna,

- Polzela,

- Mislinja,

- Kamnik,

- Ljubno ob Savinji,

- Kranj,

- Ajdovščina-Vipava.

Podobno smo območja dvajsetih največjih mrzlih točk poimenovali po pokrajini, kjer ležijo (slika 4):

- Kras,

- Suha krajina,

- Javorniki,

- Nanos-Hrušica,

- Ptujsko polje,

- Kočevski rog,

- Menišija,

- Ljubljansko barje,

- Loški potok,

- Koprska brda,

- Vremščica (slika 2),

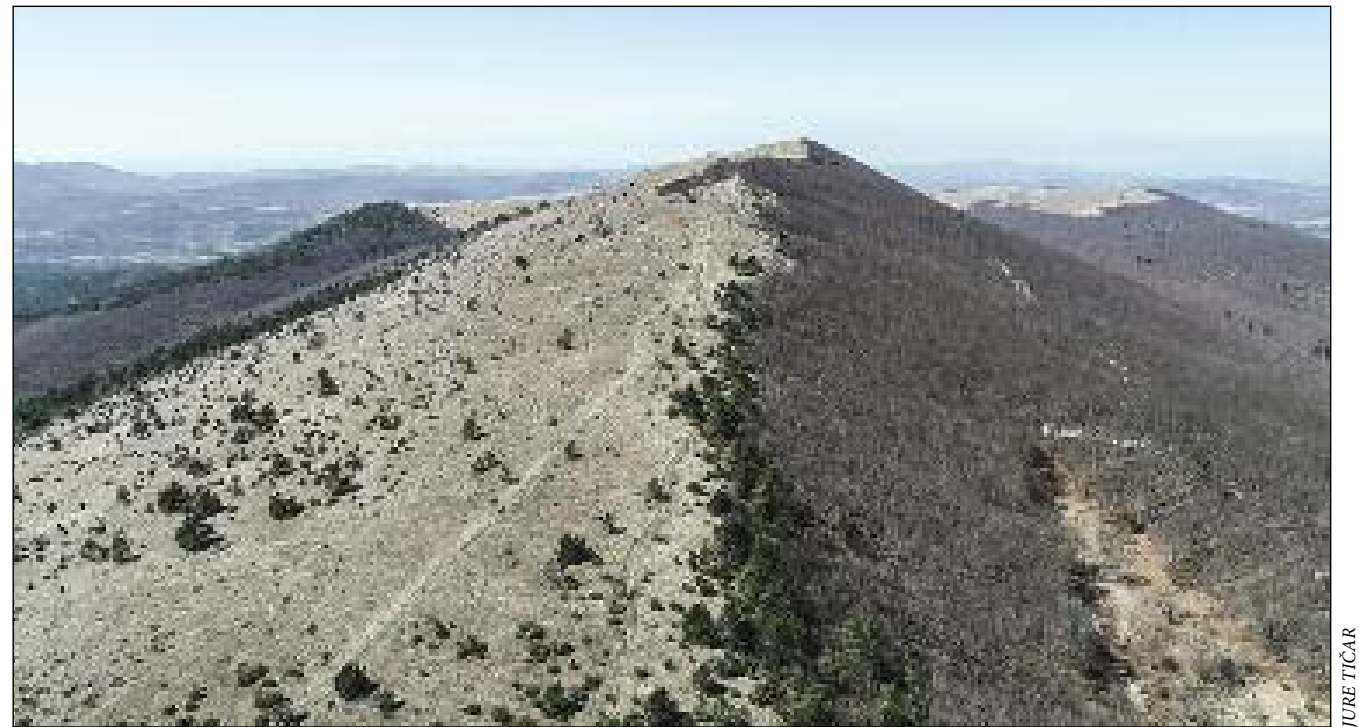

Slika 2: Enolična planotasta pokrajina okrog Vremščice med Divačo in Pivko je primer pokrajinske mrzle točke in spada $v$ skupino mrzlih točk na dinarskih in sredozemskih planotah ter dinarskih podoljih in ravnikih. 
- Bela krajina (Črnomelj),

- Ljubljansko polje,

- Brkini,

- Janško hribovje,

- Kranjsko polje,

- Vipavska brda,

- Dravinjske gorice,

- Bela krajina (Metlika),

- Ravensko.

\section{Metode dela}

Za razvrščanje pokrajinskih točk v skupine smo izbrali Wardovo metodo (Ward 1963). Ta, tudi v slovenski geografiji že večkrat uporabljena metoda (Hrvatin 1998; Perko 1998; 2009; Frantar in Hrvatin 2005; Petek 2005; Komac 2006; Bole 2008), spada med hierarhične metode, ki ne zahtevajo vnaprej opredeljenega končnega število skupin, postopno združevanje $\mathrm{v}$ skupine pa je možno zelo nazorno prikazati z drevesom združevanja, dendrogramom (Ferligoj 1989; slika 3), kjer drevesni listi predstavljajo statistične enote, drevesne veje statistične skupine, točke, kjer se veje razcepijo oziroma združijo, pa raven združevanja skupin.

Statistično razvrščanje v skupine vključuje naslednje korake (Ferligoj 1989):

- izbiranje enot,

- izbiranje spremenljivk,

- računanje podobnosti med enotami,

- izbiranje ustrezne metode razvrščanja enot v skupine,

- ocenjevanje dobljenih skupin.

V našem primeru so enote pokrajinske točke. Kot rečeno, smo izbrali 20 po površini največjih pokrajinskih vročih točk in 20 po površini največjih pokrajinskih mrzlih točk (slika 4).

Med spremenljivkami smo izbrali povprečne vrednosti 20 morfometričnih kazalnikov (Hrvatin 2016) in jih zaradi raznovrstnih vrednosti standardizirali (Ferligoj 1989, 20). Uporabili smo običajni način standardizacije, pri katerem smo od aritmetične sredine posameznega morfometričnega kazalnika pokrajinske vroče ali mrzle točke odšteli aritmetično sredino ustreznega kazalnika za območje cele Slovenije in delili s standardnim odklonom istega kazalnika prav tako na območju cele države (Ferligoj 1989, 21).

V tuji literaturi obstaja več preglednih predstavitev morfometričnih kazalnikov (Moore, Grayson in Ladson 1991; Wilson in Gallant 2000; Shary, Sharaya in Mitusov 2002; Pike, Evans in Hengl 2009; Wilson 2012). Pri izboru naših morfometričnih kazalnikov, ki temeljijo na 25-meterskem digitalnem modelu višin, smo pazili, da kar najbolje zajemajo oziroma predstavljajo izoblikovanost površja in da se medsebojno ne podvajajo (Hrvatin in Perko 2016). Izbrani kazalniki so (številka v oklepaju pomeni številko na $\mathrm{x}$ osi grafov na slikah od 5 do 11$)$ :

- višina površja (1),

- naklon površja (2),

- ekspozicija površja (3),

- ukrivljenost površja (4),

- navpična ukrivljenost površja (5),

- vodoravna ukrivljenost površja (6),

- standardni odklon višine površja (7),

- standardni odklon naklona površja (8),

- standardni odklon ekspozicije površja (9), 


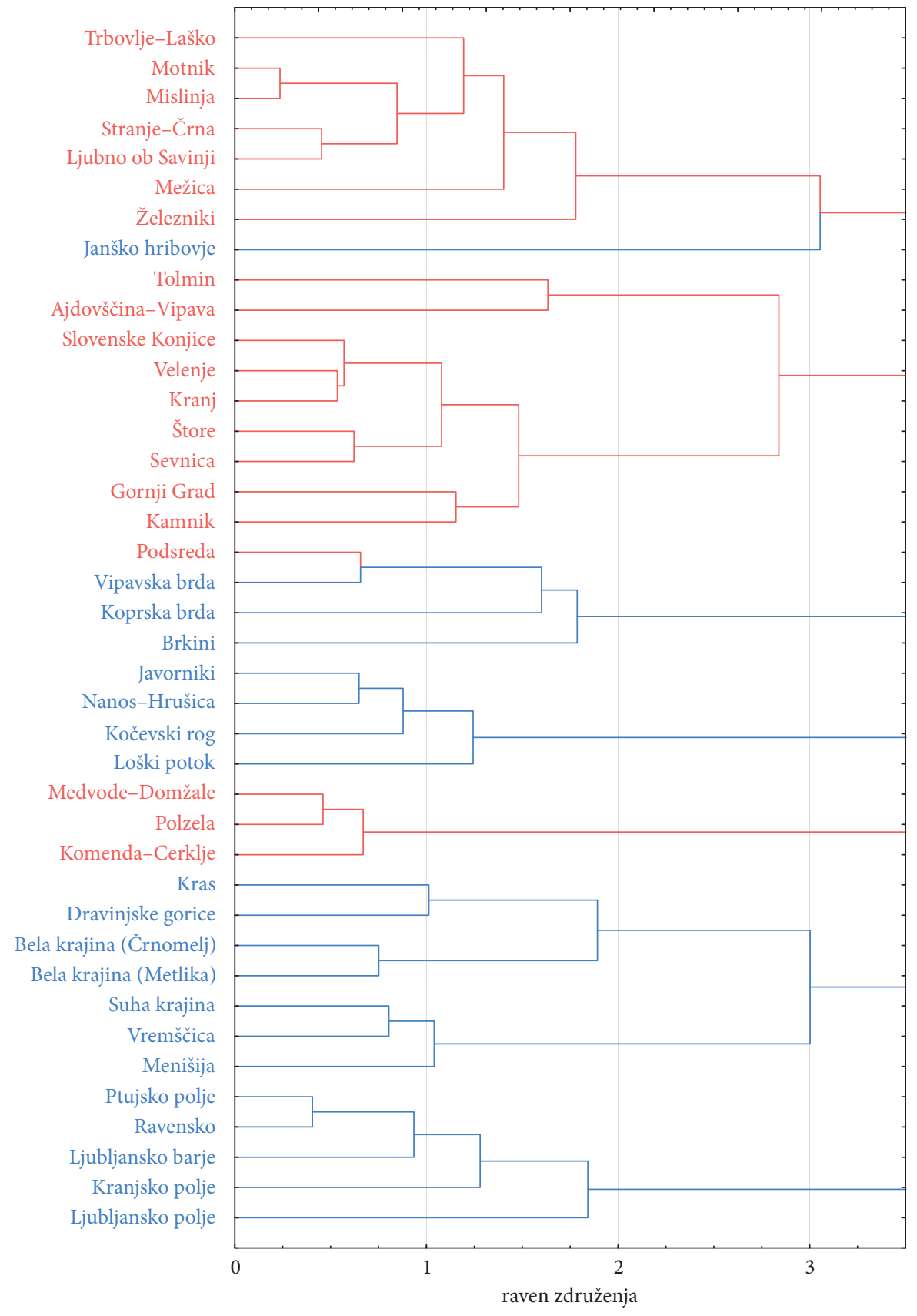

Slika 3: Drevesni diagram združevanja pokrajinskih vročih in mrzlih točk glede na morfometrične kazalnike. 
- standardni odklon ukrivljenosti površja (10),

- standardni odklon navpične ukrivljenosti površja (11),

- standardni odklon vodoravne ukrivljenosti površja (12),

- skupni koeficient razgibanosti površja (13),

- tekstura površja (14),

- indeks ukrivljenosti površja (15),

- višinsko razmerje površja (16),

- topografski pozicijski indeks (17),

- indeks vlažnosti (18),

- indeks moči vodnega toka (19) in

- indeks zmogljivosti prenosa usedlin (20).

Z Wardovo metodo smo preverjali morfometrično podobnosti med pokrajinskimi točkami in upravičenost uvrstitve neke pokrajinske točke med vroče ali mrzle točke. Najprej smo za vsako pokrajinsko točko ugotovili povprečno vrednost posameznih morfometričnih kazalnikov, nato pa z evklidskimi razdaljami ugotavljali sorodnost med pokrajinskimi točkami.

Evklidska razdalja je geometrična razdalja v večrazsežnostnem prostoru. Med dvema pokrajinskima točkama jo izračunamo tako, da seštejemo vse kvadrirane razlike med istovrstnima podatkoma obeh pokrajinskih točk, dobljeno vsoto pa korenimo.

Manjša je evklidska razdalja med dvema pokrajinskima točkama, bolj podobne vrednosti morfometričnih kazalnikov imata. Če je evklidska razdalja med dvema pokrajinskima točkama 0 , imata popolnoma enake vrednosti morfometričnih kazalnikov. V morfometričnem smislu sta si taki pokrajinski točki enaki (Perko 1998).

Pri poimenovanju skupin pokrajinskih vročih in mrzlih točk smo si pomagali z imeni devetih pokrajinskih tipov oziroma štirih skupin pokrajinskih tipov iz pokrajinske tipizacije Slovenije (Perko, Hrvatin in Ciglič 2015):

- alpske pokrajine (alpska gorovja, alpska hribovja, alpske ravnine),

- panonske pokrajine (panonska gričevja, panonske ravnine),

- dinarske pokrajine (dinarske planote, dinarska podolja in ravniki),

- sredozemske pokrajine (sredozemska gričevja, sredozemske planote).

\section{Morfometrični tipi pokrajinskih vročih in mrzlih točk}

S hierarhično klasifikacijo smo določili sedem skupin pokrajinskih točk (slika 4). V dveh skupinah so samo pokrajinske vroče točke, $v$ treh pa samo pokrajinske mrzle točke. V dveh skupinah se skupaj pojavljajo tako vroče kot tudi mrzle točke: $\mathrm{v}$ skupini vročih točk $\mathrm{v}$ alpskih hribovjih na stiku $\mathrm{z}$ alpskimi gorovji je ob sedmih vročih točkah še ena mrzla, v skupini mrzlih točk v sredozemskih gričevjih pa je ob treh mrzlih točkah še ena vroča. Največ pokrajinskih vročih točk je zbranih v skupini vročih točk $\mathrm{v}$ alpskih hribovjih na stiku $\mathrm{z}$ alpskimi ravninami, panonskimi gričevji in dinarskimi planotami (devet), največ pokrajinskih mrzlih točk pa v skupini mrzlih točk na dinarskih in sredozemskih planotah ter dinarskih podoljih in ravnikih (sedem). Imena skupin smo določili po legi pokrajinskih vročih in mrzlih točk glede na pokrajinske tipe: alpska gorovja, alpska hribovja, alpske ravnine, panonska gričevja, panonske ravnine, dinarske planote, dinarska podolja in ravniki, sredozemska gričevja, sredozemske planote (Perko, Hrvatin in Ciglič 2015).

Slika 4: Lega 20 največjih pokrajinskih vročih točk (rdeče) in 20 največjih pokrajinskih mrzlih točk (modro). $>$ str. 42 


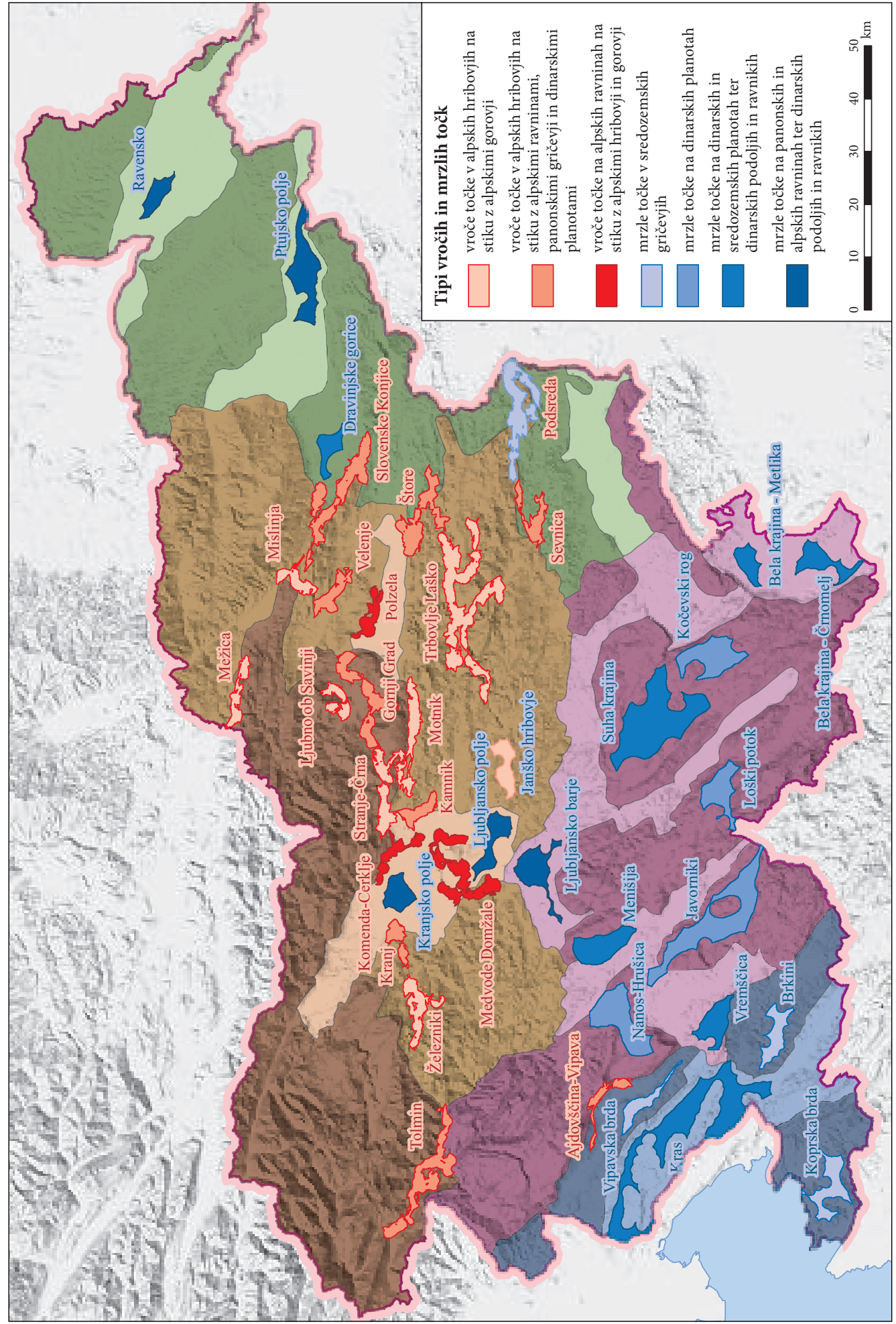




\subsection{Vroče točke $\mathrm{v}$ alpskih hribovjih na stiku $\mathrm{z}$ alpskimi gorovji}

V prvo skupino so se uvrstile vroče točke Trbovlje-Laško, Motnik, Mislinja, Stranje-Črna, Ljubno ob Savinji, Mežica in Železniki ter mrzla točka Janško hribovje. Glede na pokrajinske tipe pripada večina vročih in mrzlih točk alpskim hribovjem na stiku z alpskimi gorovji. Pri Ljubnem ob Savinji, Mežici, Stranjah-Črni in Motniku delež alpskega gorskega sveta celo presega delež alpskega hribovitega sveta.

Glede na slovensko povprečje posameznih morfometričnih kazalnikov je kar osemnajst kazalnikov v tej skupini nekoliko nad povprečjem. Rahlo pod povprečjem sta le višinsko razmerje površja in indeks vlažnosti (slika 5).

$\mathrm{Z}$ višjimi vrednostmi posameznih kazalnikov, na primer standardnega odklona ukrivljenosti površja, standardnega odklona vodoravne ukrivljenosti površja, teksture površja in višinskega razmerja površja, v skupinici najbolj odstopa Janško hribovje. Zaradi vključitve Janškega hribovja je ta skupina najbolj heterogena.

Samo enemu pokrajinskemu tipu pripadajo tri vroče in ena mrzla točka. Vroči pokrajinski točki Trbovlje-Laško in Železniki ter mrzla pokrajinska točka Janško hribovje obsegajo samo alpska hribovja, vroča pokrajinska točka Ljubno ob Savinji pa obsega samo alpsko gorovje.

\subsection{Vroče točke $\mathrm{v}$ alpskih hribovjih na stiku $\mathrm{z}$ alpskimi ravninami, panonskimi gričevji in dinarskimi planotami}

V drugo, največjo skupino so se uvrstile vroče točke Tolmin, Ajdovščina-Vipava, Slovenske Konjice, Velenje, Kranj, Štore, Sevnica, Gornji Grad in Kamnik. Večina pokrajinskih vročih točk pripada alpskim hribovjem na stiku $\mathrm{z}$ alpskimi ravninami, panonskimi gričevji in dinarskimi planotami.

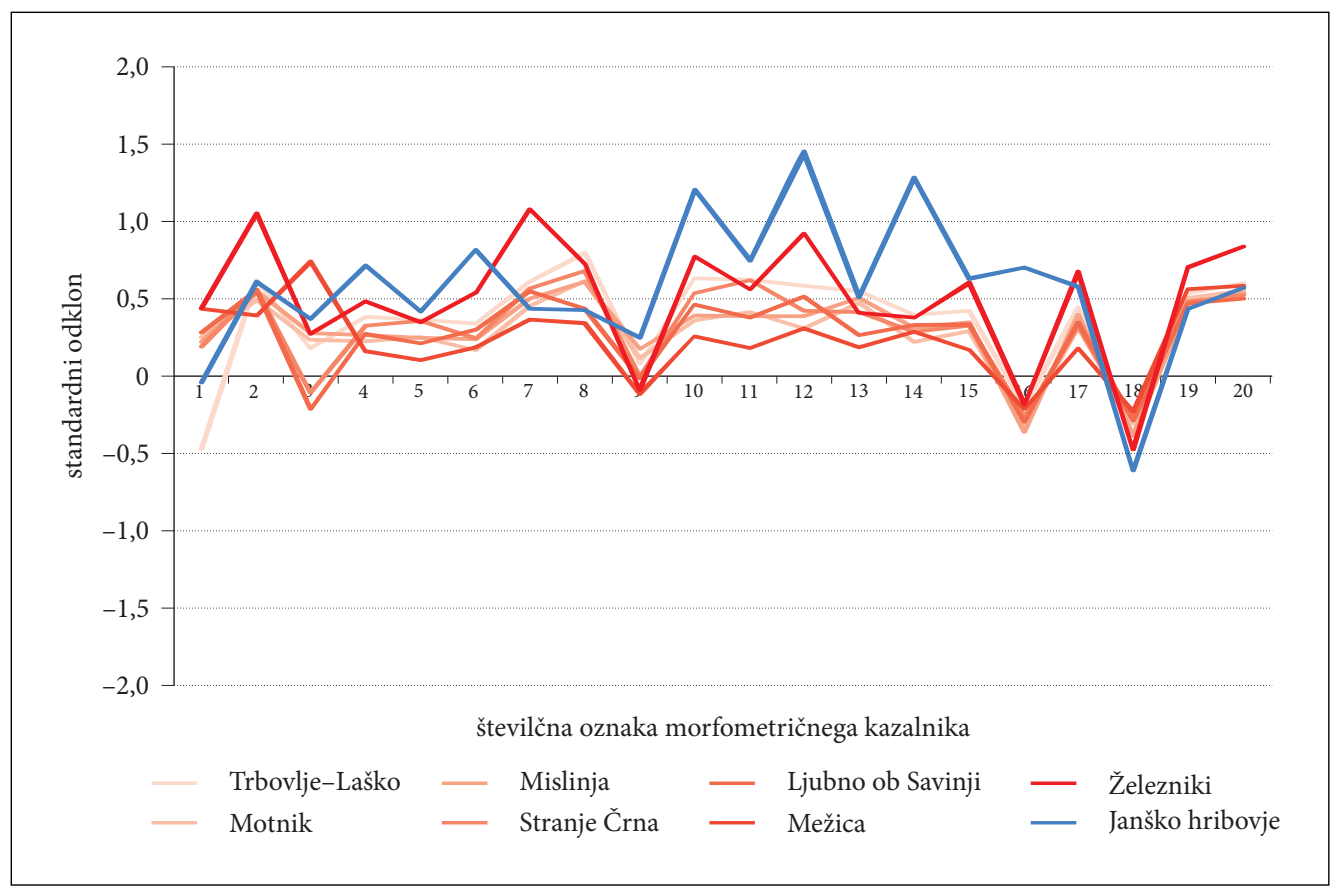

Slika 5: Diagram vrednosti morfometričnih kazalnikov skupine vročih točk alpskih hribovij na stiku $z$ alpskimi gorovji. 
Delež alpskih hribovij ni povsod največji. Pri Tolminu in Gornjem Gradu ga presega delež alpskih gorovij, pri Sevnici in Slovenskih Konjicah delež panonskih gričevij in pri Ajdovščini-Vipavi delež sredozemskih gričevij.

Glede na slovenske razmere je petnajst morfometričnih kazalnikov te skupine rahlo nad povprečjem, rahlo pod povprečjem pa so vrednosti za višino površja, vodoravno ukrivljenost površja, standardni odklon vodoravne ukrivljenosti površja, višinsko razmerje površja in indeks vlažnosti (slika 6).

$\mathrm{V}$ tej razmeroma heterogeni in najštevilčnejši skupini pokrajinskih vročih točk lahko ločimo dve manjši podskupini. Prvo sestavljata vroči točki Tolmin in Ajdovščina-Vipava, drugo pa preostalih sedem vročih točk. Zlasti vroča točka Tolmin izstopa z nadpovprečnimi vrednostmi naklona površja, standardnega odklona višine površja in indeksa moči vodnega toka.

Samo enemu pokrajinskemu tipu, alpskim hribovjem, pripada le pokrajinska vroča točka Velenje.

\subsection{Mrzle točke v sredozemskih gričevjih}

V tretjo skupino so se uvrstile vroča točka Podsreda ter mrzle točke Vipavska brda, Koprska brda in Brkini. Glede na pokrajinske tipe pripada vroča točka alpskim hribovjem in panonskim gričevjem, vse tri mrzle točke v skupini pa so tipični predstavniki sredozemskih gričevij (slika 7).

Kar osemnajst morfometričnih kazalnikov te skupine je nekoliko nad slovenskim povprečjem, pod povprečjem sta le višina površja in indeks vlažnosti. Večje pozitivno odstopanje nad državnim povprečjem je opazno samo pri višinskem razmerju površja v Brkinih in Koprskih brdih, nekoliko večje negativno odstopanje pa pri višini površja v Koprskih in Vipavskih brdih.

Vse tri mrzle točke pripadajo samo enemu pokrajinskemu tipu: Vipavska brda, Koprska brda in Brkini obsegajo samo sredozemska gričevja.

\subsection{Mrzle točke na dinarskih planotah}

V četrto skupino so se uvrstile mrzle točke Javorniki, Nanos-Hrušica, Kočevski rog in Loški potok. Njihovo ozemlje pripada predvsem dinarskim planotam in nekatere le v manjši meri segajo še na območje dinarskih podolij in ravnikov.

Skupina je homogena in nobena od pokrajinskih mrzlih točk ne izstopa. V primerjavi s slovenskimi razmerami so skoraj vsi morfometrični kazalniki te skupine zelo blizu povprečja. Enajst kazalnikov je rahlo pod povprečjem, osem pa rahlo nad njim. Od povprečja izraziteje izstopajo samo večje vrednosti za višino površja (slika 8).

Samo enemu pokrajinskemu tipu, dinarskim planotam, pripadata pokrajinski mrzli točki Kočevski rog in Loški potok.

\subsection{Vroče točke na alpskih ravninah na stiku $\mathrm{z}$ alpskimi hribovji in gorovji}

V peto, najmanjšo skupino so se uvrstile vroče točke Medvode-Domžale, Polzela in Komenda-Cerklje. Največji delež ozemlja točk Medvode-Domžale in Komenda-Cerklje pripada alpskim ravninam, medtem ko sestavljajo območje točke Polzela predvsem alpska hribovja.

Skupina je med vsemi najbolj homogena in odstopanja med vročimi točkami so komaj opazna. Kar devetnajst morfometričnih kazalnikov te skupine je nekoliko pod slovenskim povprečjem, med negativnimi vrednostmi še najbolj izstopa višinsko razmerje površja. Nadpovprečne vrednosti ima le indeks vlažnosti (slika 9).

Nobena od pokrajinskih vročih točk v tej skupini ne pripada samo enemu pokrajinskemu tipu. 


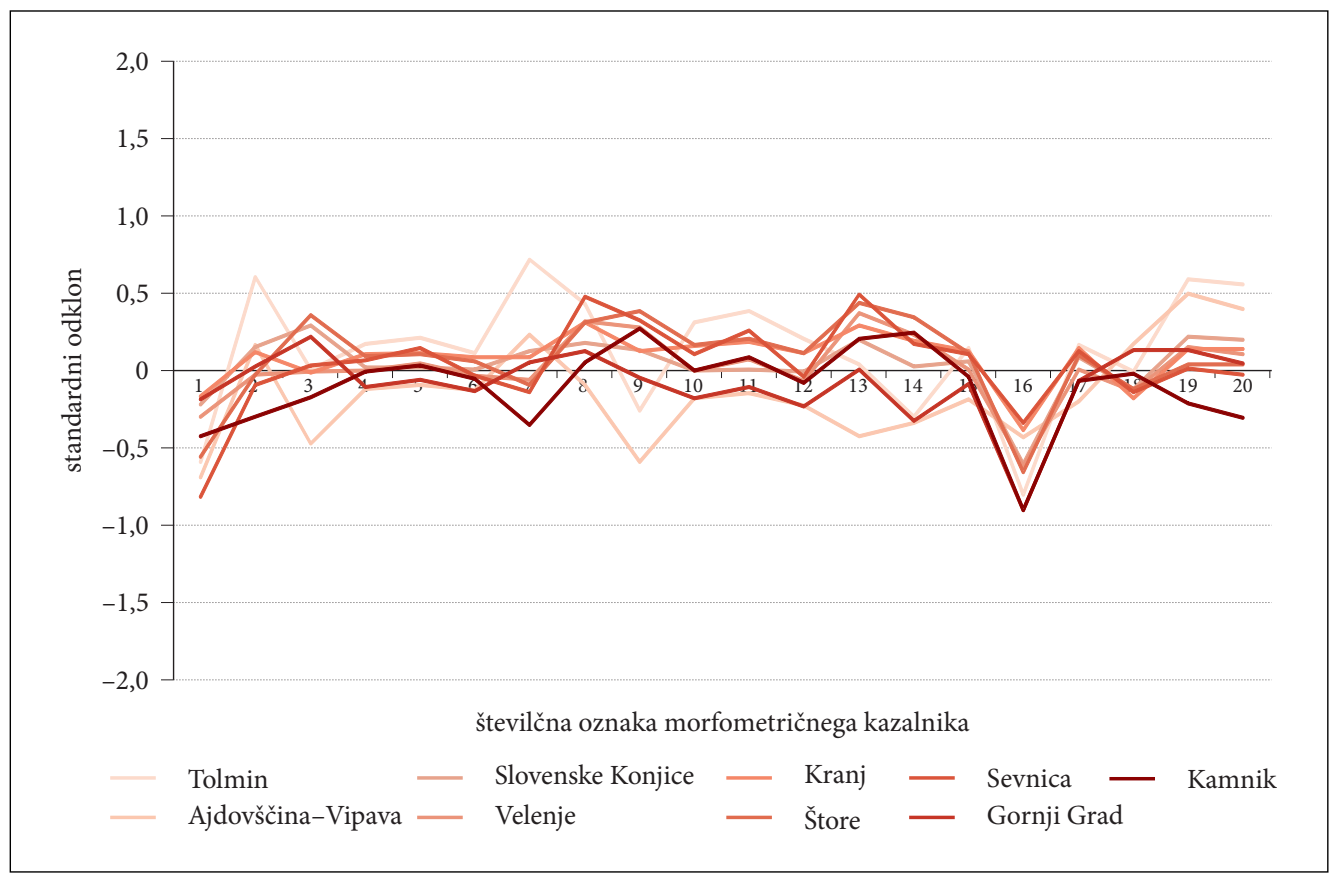

Slika 6: Diagram vrednosti morfometričnih kazalnikov skupine vročih točk alpskih hribovij na stiku $z$ alpskimi ravninami, panonskimi gričevji in dinarskimi planotami.

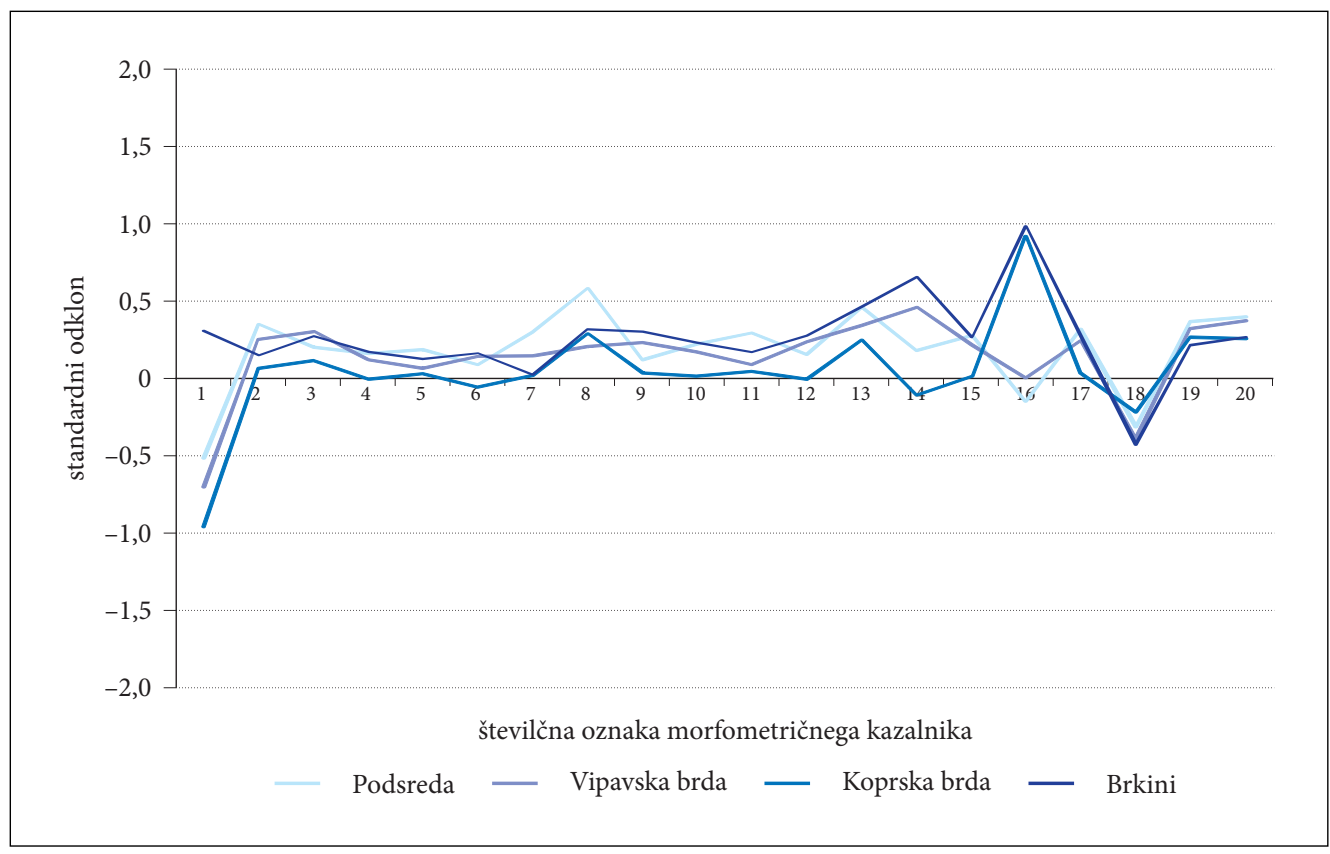

Slika 7: Diagram vrednosti morfometričnih kazalnikov skupine mrzlih točk sredozemskih gričevij. 


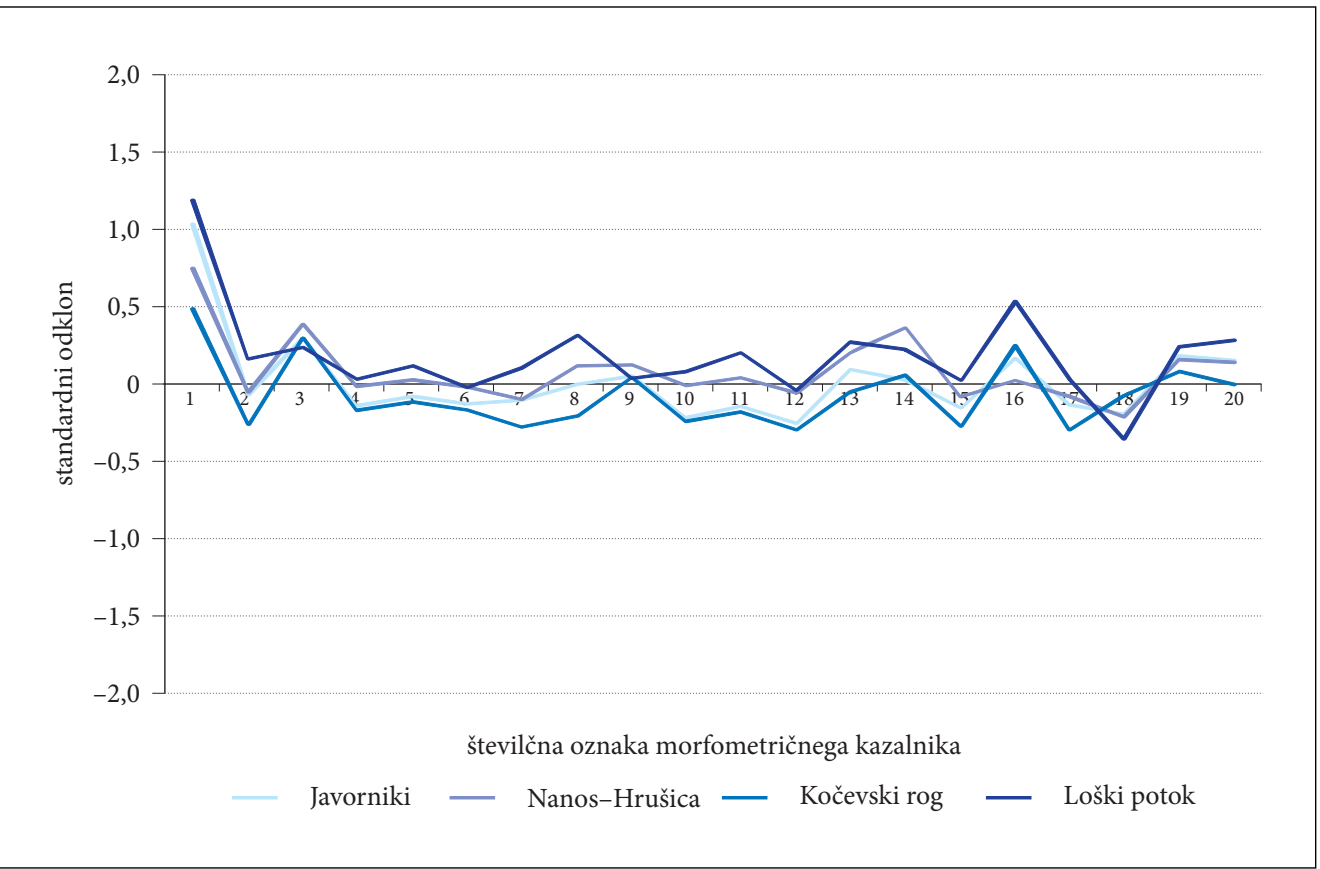

Slika 8: Diagram vrednosti morfometričnih kazalnikov skupine mrzlih točk dinarskih planot.

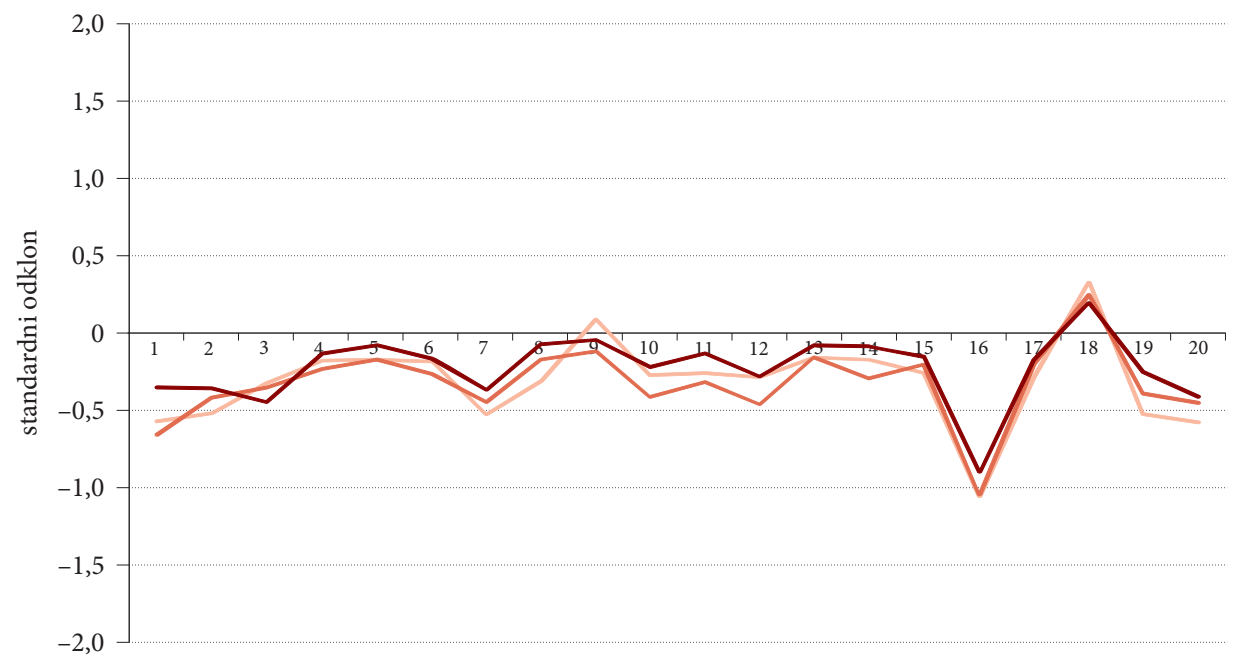

številčna oznaka morfometričnega kazalnika

Medvode-Domžale — Polzela — Komenda-Cerklje

Slika 9: Diagram vrednosti morfometričnih kazalnikov skupine vročih točk alpskih ravnin na stiku $z$ alpskimi hribovji in gorovji. 


\subsection{Mrzle točke na dinarskih in sredozemskih planotah ter dinarskih podoljih in ravnikih}

V šesto skupino so se uvrstile mrzle točke Kras, Dravinjske gorice, Bela krajina (območje Črnomlja), Bela krajina (območje Metlike), Suha krajina, Vremščica in Menišija. To je največja skupina, ki jo sestavljajo izključno pokrajinske mrzle točke.

Večina pokrajinskih mrzlih točk pripada dinarskim planotam ter dinarskim podoljem in ravnikom, zraven pa sta uvrščeni še točki, ki sploh ne ležita na dinarskem svetu. Dravinjske gorice pripadajo panonskim gričevjem, Kras pa k sredozemskim planotam. Zaradi tega spada ta skupina med najbolj heterogene.

Kar šestnajst morfometričnih kazalnikov te skupine je nekoliko podpovprečnih glede na slovenske razmere. Med njimi najbolj izstopajo naklon površja, standardni odklon višine površja in indeks zmogljivosti prenosa usedlin. Med štirimi kazalniki, ki so nad državnim povprečjem pa edino izstopa standardni odklon ekspozicije površja (slika 10).

Štiri mrzle točke iz te skupine pripadajo samo enemu pokrajinskemu tipu: Dravinjske gorice panonskim gričevjem, Bela krajina (območje Črnomlja) in Bela krajina (območje Metlike) dinarskim ravnikom ter Suha krajina dinarskim planotam. Z ogromno večino ozemlja spada k sredozemskim planotam tudi pokrajinska mrzla točka Kras, ki pa vendarle z zanemarljivim deležem $(0,02 \%)$ sega še na sredozemska gričevja.

\subsection{Mrzle točke na panonskih in alpskih ravninah ter dinarskih podoljih in ravnikih}

V sedmo skupino so se uvrstile mrzle točke Ptujsko polje, Ravensko, Ljubljansko barje, Kranjsko polje in Ljubljansko polje. $\mathrm{V}$ vseh primerih gre za območja ravninskega sveta, ki sicer spadajo k različnim skupinam pokrajinskih tipov: panonskim, dinarskim in alpskim pokrajinam.

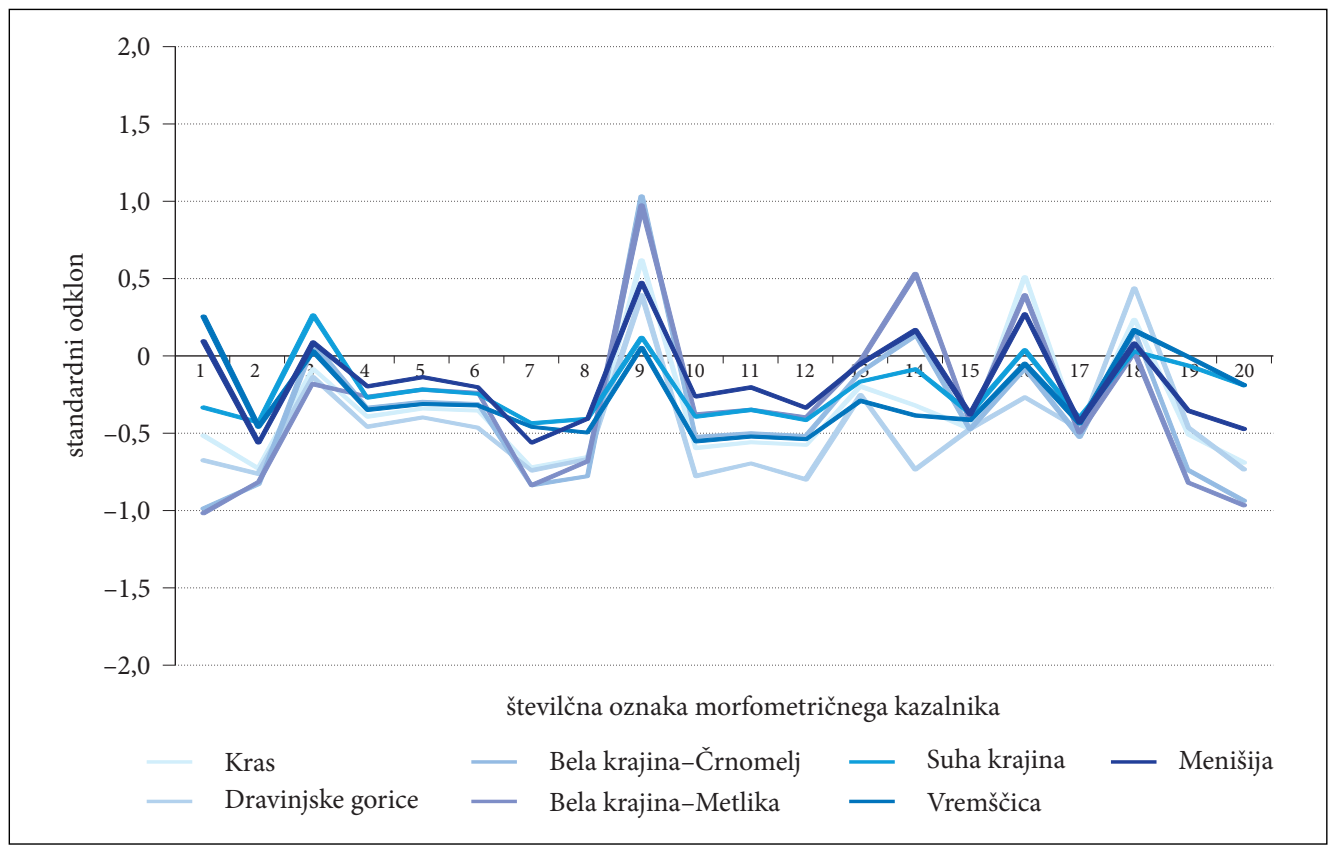

Slika 10: Diagram vrednosti morfometričnih kazalnikov skupine mrzlih točk dinarskih in sredozemskih planot ter dinarskih podolij in ravnikov. 


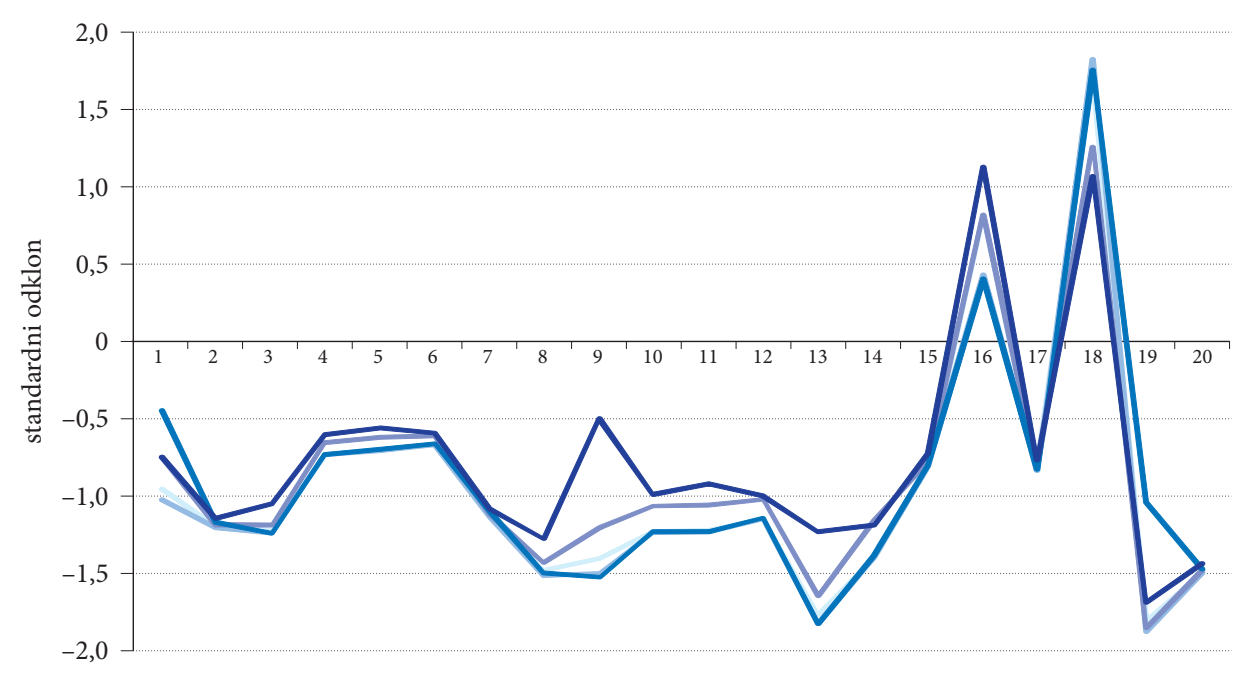

številčna oznaka morfometričnega kazalnika

$\begin{array}{llll}\text { Ptujsko polje } & - & \text { Ljubljansko barje } \quad-\quad \text { Ljubljansko polje } \\ \text { Ravensko } & - & \text { Kranjsko polje }\end{array}$

Slika 11: Diagram vrednosti morfometričnih kazalnikov skupine mrzlih točk panonskih in alpskih ravnin ter dinarskih podolij in ravnikov.

Primerjava morfometričnih kazalnikov s povprečnimi slovenskimi razmerami kaže daleč največja odstopanja. Medtem ko sta kazalnika višinsko razmerje površja in indeks vlažnosti visoko nad državnim povprečjem, je vseh preostalih osemnajst kazalnikov večinoma močno podpovprečnih (slika 11).

Vseh pet mrzlih točk pripada samo enemu pokrajinskemu tipu: Ptujsko polje in Ravensko panonskim ravninam, Ljubljansko barje dinarskim podoljem, Kranjsko in Ljubljansko polje pa alpskim ravninam.

\section{Sklep}

V prispevku je predstavljena razvrstitev morfometričnih tipov pokrajinskih vročih in mrzlih točk v Sloveniji, ki smo jo opravili na temelju dvajsetih morfometričnih kazalnikov. Upoštevali smo standardizirane morfometrične kazalnike za 20 največjih pokrajinskih vročih točk in 20 največjih pokrajinskih mrzlih točk ter jih razvrstili v skupine na osnovi evklidskih razdalj in Wardove hierarhične metode razvrščanja.

Rezultat statističnega razvrščanja v skupine je sedem morfometričnih tipov pokrajinskih vročih in mrzlih točk:

- vroče točke v alpskih hribovjih na stiku z alpskimi gorovji (poglavje 3.1),

- vroče točke $v$ alpskih hribovjih na stiku $\mathrm{z}$ alpskimi ravninami, panonskimi gričevji in dinarskimi planotami (poglavje 3.2),

- mrzle točke v sredozemskih gričevjih (poglavje 3.3),

- mrzle točke na dinarskih planotah (poglavje 3.4),

- vroče točke na alpskih ravninah na stiku z alpskimi hribovji in gorovji (poglavje 3.5),

- mrzle točke na dinarskih in sredozemskih planotah ter dinarskih podoljih in ravnikih (poglavje 3.6),

- mrzle točke na panonskih in alpskih ravninah ter dinarskih podoljih in ravnikih (poglavje 3.7). 
V dveh skupinah so samo pokrajinske vroče točke, $v$ treh pa samo pokrajinske mrzle točke. Največ pokrajinskih vročih točk, kar devet, je zbranih v skupini vročih točk $\mathrm{v}$ alpskih hribovjih na stiku $\mathrm{z}$ alpskimi ravninami, panonskimi gričevji in dinarskimi planotami, največ pokrajinskih mrzlih točk, sedem, pa v skupini mrzlih točk na dinarskih in sredozemskih planotah ter dinarskih podoljih in ravnikih.

Skupine se razlikujejo tudi po homogenosti, to je na podlagi ravni združevanja, ki je razvidna iz drevesnega diagrama združevanja pokrajinskih vročih in mrzlih točk glede na morfometrične kazalnike (slika 3).

Med skupinami vročih pokrajinskih točk je najbolj homogena skupinica treh vročih točk na alpskih ravninah na stiku $\mathrm{z}$ alpskimi hribovji in gorovji, najbolj heterogena pa skupina vročih točk $\mathrm{v}$ alpskih hribovjih na stiku $\mathrm{z}$ alpskimi gorovji, tudi zato, ker vključuje mrzlo točko.

Med skupinami mrzlih pokrajinskih točk je najbolj homogena skupina štirih mrzlih točk dinarskih planotah, najbolj heterogena pa skupina mrzlih točk na dinarskih in sredozemskih planotah ter dinarskih podoljih in ravnikih.

V dveh skupinah se skupaj pojavljajo tako vroče kot tudi mrzle točke. V skupino vročih točk v alpskih hribovjih na stiku $\mathrm{z}$ alpskimi gorovji se je uvrstila še mrzla točka Janško hribovje prav tako iz alpskega hribovja, v skupino mrzlih točk v sredozemskih gričevjih pa še vroča točka Podsreda na stiku alpskega hribovja in panonskega gričevja.

Od 40 pokrajinskih vročih in mrzlih točk sta v nasprotno skupino uvrščeni le dve, kar je komaj $5 \%$. Ker so bile pokrajinske vroče in mrzle točke določene na podlagi reliefnih, kamninskih in vegetacijskih tipov, smo pričakovali bistveno bolj pomešane skupine. Visok delež čistih morfometričnih skupin torej kaže, da so morfološke prvine pokrajine dejansko zelo pomembne pri razlikovanju vročih oziroma mrzlih pokrajinskih točk.

Na podoben način lahko pokrajinske vroče in mrzle točke uvrščamo v skupine tudi glede na druge pokrajinske prvine, recimo raznolikost rabe zemljišč, ali glede na njihove geometrične lastnosti, recimo obliko in velikost.

Zahvala: Prispevek temelji na raziskovalnem programu Geografija Slovenije (P6-0101), ki ga financira Javna agencija za raziskovalno dejavnost Republike Slovenije, in raziskovalnem projektu Pokrajinska raznolikost in vroče točke Slovenije (L6-6852), ki sta ga sofinancirali Javna agencija za raziskovalno dejavnost Republike Slovenije ter Slovenska akademija znanosti in umetnosti.

\section{Viri in literatura}

Bole, D: 2008: Ekonomska preobrazba slovenskih mest. Geografija Slovenije 19. Ljubljana.

Ciglič, R., Perko, D. 2013: Europe’s landscape hotspots. Acta geographica Slovenica 53-1. Ljubljana. DOI: https://doi.org/10.3986/AGS53106

Ferligoj, A. 1989: Razvrščanje v skupine. Metodološki zvezki 4. Ljubljana.

Frantar, P., Hrvatin, M. 2005: Pretočni režimi v Sloveniji med letoma 1971 in 2000. Geografski vestnik 77-2.

Hrvatin., M. 1998: Discharge regimes in Slovenia. Geografski zbornik 38.

Hrvatin, M. 2016: Morfometrične značilnosti površja na različnih kamninah v Sloveniji. Doktorsko delo, Fakulteta za humanistične študije Univerze na Primorskem. Koper.

Hrvatin, M., Perko, D. 2016: Morfometrične razlike med pokrajinskimi vročimi in mrzlimi točkami. Digitalni podatki, GIS v Sloveniji 13. Ljubljana.

Komac, B. 2006: Dolec kot značilna reliefna oblika dolomitnega površja. Geografija Slovenije 13. Ljubljana. Moore, I. D., Grayson, R. B., Ladson, A. R. 1991: Digital terrain modelling: A review of hydrological, geomorphological, and biological applications. Hydrological processes 5-1. DOI: https://doi.org/ 10.1002/hyp.3360050103 
Perko, D. 1998: Regionalization of Slovenia. Geografski zbornik 38.

Perko, D. 2009: Tipi naravne pokrajine kot dejavnik regionalnega razvoja in regionalnih razlik v Sloveniji. Razvojni izzivi Slovenije, Regionalni razvoj 2. Ljubljana.

Perko, D., Ciglič, R., Hrvatin, M. 2017: Determination of landscape hotspots of Slovenia. Acta geographica Slovenica 57-1. DOI: https://doi.org/10.3986/AGS.4618

Perko, D., Hrvatin, M., Ciglič, R. 2015: A methodology for natural landscape typification of Slovenia. Acta geographica Slovenica 55-2. DOI: https://doi.org/10.3986/AGS.1938

Petek, F. 2005: Spremembe rabe tal v slovenskem alpskem svetu. Geografija Slovenije 11. Ljubljana.

Pike, R. J., Evans, I. S., Hengl, T. 2009: Geomorphometry: a brief guide. Geomorphometry: Concepts, Software, Applications. Amsterdam. DOI: https://doi.org/10.1016/S0166-2481(08)00001-9

Shary, P. A., Sharaya, L. S., Mitusov, A. V. 2002: Fundamental quantitative methods of land surface analysis. Geoderma 107, 1-2. DOI: https://doi.org/10.1016/S0016-7061(01)00136-7

Ward, J. H. 1963: Hierarchical grouping to optimize an objective function. American Statistical Association Journal 58-301. DOI: https://doi.org/10.1080/01621459.1963.10500845

Wilson, J. P. 2012: Digital terrain modelling. Geomorphology 137-1. DOI: https://doi.org/10.1016/ j.geomorph.2011.03.012

Wilson, J. P., Gallant, J. C. 2000: Digital terrain analysis. Terrain Analysis: Principles and Applications. New York.

\section{Summary: Morphometric types of landscape hotspots and coldspots in Slovenia}

(translated by Mauro Hrvatin and Drago Perko)

Based on digital data on relief, rock, and vegetation, a geographic information system was used to calculate landscape diversity of Slovenia. Areas with high landscape diversity are landscape hotspots, while areas with low landscape diversity are landscape coldspots.

The aim of the study was to determine in particular, whether or not there are some common characteristics for such landscape hotspots and coldspots, whether they can be classified into groups according to these characteristics, and whether the individual groups are uniform, made up only of hotspots or coldspots, or mixed, that is, they are composed simultaneously from hotspots and coldspots.

The paper presents the cluster analysis and the classification of morphometric types of landscape hotspots and coldspots in Slovenia, which was carried out on the basis of twenty morphometric indicators. We took into account standardized morphometric indicators for the 20 largest hotspots and the 20 largest cold spots and clustered them into groups based on Euclidean distances and Ward's hierarchical method.

The results of statistical clustering are seven morphometric types of landscape hotspots and coldspots:

- hotspots in Alpine hills on contact with Alpine mountains;

- hotspots in Alpine hills on contact with Alpine plains, Pannonian low hills and Dinaric lowlands;

- coldspots in the Mediterranean low hills;

- coldspots on the Dinaric plateaus;

- hotspots on the Alpine plains in contact with the Alpine hills and mountains;

- coldspots on Dinaric and Mediterranean plateaus and Dinaric lowlands;

- coldspots on the Pannonian, Alpine and Dinaric lowlands.

In two groups there are only landscape hotspots, and in three, only landscape coldspots. The highest number of landscape hotspots (nine) is collected in the group of hotspots in the Alpine hills on contact with Alpine plains, Pannonian low hills and Dinaric lowlands. Most of the landscape's coldspots (seven) is collected in the group of coldspots on the Dinaric and Mediterranean plateaus and Dinaric lowlands. 
Among the hotspots, the most homogeneous group includes three hotspots on the Alpine plains on contact with Alpine hills and mountains. The most heterogeneous group of hotspots includes seven hotspots and one coldspot in Alpine hills on contact with the Alpine mountains.

Among the landscape coldspots, the most homogeneous group comprises four coldspots on Dinaric plateaus. The most heterogeneous group of coldspots includes seven coldspots on the Dinaric and Mediterranean plateaus and Dinaric lowlands.

In two groups, both hotspots and coldspots appear together. The group of hotspots in the Alpine hills on the contact with the Alpine mountains comprises the coldspot of the Janče hills (Janško hribovje), while the group of coldspots in the Mediterranean low hills includes the hotspot of Podsreda on the contact of the Alpine hills and the Pannonian low hills.

A high proportion of homogeneous morphometric groups show that the morphological elements of the landscape are important in distinguishing landscape hotspots or coldspots. 